University of Nebraska - Lincoln

DigitalCommons@University of Nebraska - Lincoln

$4-2003$

\title{
Phyllodistomum funduli n. sp. (Trematoda: Gorgoderidae) from Fundulus sciadicus Cope from Cedar Creek in Western Nebraska
}

Jaclyn Helt

St. Helen School (Dayton, $\mathrm{OH}$ )

John J. Janvoy Jr.

University of Nebraska - Lincoln, jjanovy1@unl.edu

John Ubelaker

Southern Methodist University, ubelaker@smu.edu

Follow this and additional works at: https://digitalcommons.unl.edu/bioscijanovy

Part of the Parasitology Commons

Helt, Jaclyn; Janvoy, John J. Jr.; and Ubelaker, John, "Phyllodistomum funduli n. sp. (Trematoda: Gorgoderidae) from Fundulus sciadicus Cope from Cedar Creek in Western Nebraska" (2003). John Janovy Publications. 21.

https://digitalcommons.unl.edu/bioscijanovy/21

This Article is brought to you for free and open access by the Papers in the Biological Sciences at DigitalCommons@University of Nebraska - Lincoln. It has been accepted for inclusion in John Janovy Publications by an authorized administrator of DigitalCommons@University of Nebraska - Lincoln. 


\title{
PHYLLODISTOMUM FUNDULI N. SP. (TREMATODA: GORGODERIDAE) FROM FUNDULUS SCIADICUS COPE FROM CEDAR CREEK IN WESTERN NEBRASKA
}

\author{
Jaclyn Helt, John Janovy, Jr., and John Ubelaker \\ School of Biological Sciences, University of Nebraska-Lincoln, Lincoln, Nebraska 68588. e-mail: jhelt1@bigred.unl.edu
}

\begin{abstract}
Phyllodistomum funduli $\mathrm{n}$. sp. is described from the urinary bladder and ureters of the plains topminnow, Fundulus sciadicus, from Cedar Creek in Keith County, Nebraska $\left(41^{\circ} 11.18^{\prime} \mathrm{N}, 101^{\circ} 21.77^{\prime} \mathrm{W}\right)$. Phyllodistomum funduli differs from most other Phyllodistomum species reported in possessing an oral sucker that is larger than the acetabulum. Currently, 7 other species of Phyllodistomum have been reported to possess this trait. A comparison of $P$. funduli with these 7 other species indicates that $P$. funduli is a distinct species, lacking notches, posterior body folds, caudal projections, or cephalic glands found in some congeners. There is no published report on parasites other than monogeneans inhabiting the plains topminnow, and there is no other report of members from the Gorgoderidae inhabiting any members of the Fundulidae.
\end{abstract}

Species of Phyllodistomum (Trematoda: Gorgoderidae) are typically found in the urinary bladders of a variety of ectothermic vertebrates, primarily fishes and amphibians (Goodchild, 1943; Beilfu, 1954; Thomas, 1956; Rai, 1964; Schell, 1967; Ubelaker and Olsen, 1972; Bakke and Bailey, 1987; Hoffman, 1999), but Phyllodistomum is the only genus of its family to infect freshwater fishes. Currently, there are 29 species of Phyllodistomum found in the freshwater fishes of North America (Hoffman, 1999).

Fundulus sciadicus Cope, 1865 (Pisces: Fundulidae), the plains topminnow, is a small species that has a disjunct distribution in 2 main population centers. The first is in Nebraska and includes northeastern Colorado, eastern Wyoming, southern South Dakota, and northwestern Iowa (Lee et al., 1980). The second center is in south-central Missouri and includes southeastern Kansas and northeastern Oklahoma (Lee et al., 1980). Fundulus sciadicus is a poorly understood species, a fact that inadvertently has led to little information being published about its parasites (Ferdig et al., 1991, 1993). The 2 studies that were conducted concentrated on parasites found on the gills of these fish, whereas the present study examined the endoparasites. Ubelaker (1967) reported the new species of Phyllodistomum in $F$. sciadicus from Colorado in his doctoral dissertation, but his species description was never published.

Subsequently, Ubelaker and Olsen (1970) reported on the survival and infectivity of miracidia of this parasite, again without naming or describing it. Since this last study, there has been no published report of endoparasites occurring in the plains topminnow, and there has been no report of members from the Gorgoderidae inhabiting any members of the Fundulidae.

\section{MATERIALS AND METHODS}

Plains topminnows, along with 8 other fish species from 5 families, were collected from Cedar Creek in western Nebraska $\left(41^{\circ} 11.18^{\prime} \mathrm{N}\right.$, $101^{\circ} 21.77^{\prime} \mathrm{W}$ ) by seine during the summers of 1999-2001. Animals were placed in buckets with aerators and brought back to Cedar Point Biological Station, $13 \mathrm{~km}$ north of Ogallala, Nebraska. Fish were decapitated and examined internally for parasites.

Worms were removed from the bladder and killed in hot water, fixed in ethyl alcohol-formalin-acetic acid, stained in Semichon's acetocarmine, dehydrated, and mounted in Canada balsam (Pritchard and Kruse, 1982). Figures were drawn with the aid of a camera lucida. All measurements were taken under a magnification of $\times 40$, except for the

Received 5 September 2002; revised 30 December 2002; accepted 31 December 2002.

* Department of Biology, Southern Methodist University, Dallas, Texas 75205 . mature egg measurements, which were taken under a magnification of $\times 400$. Five mature eggs were measured for each worm. All measurements are given as a range (mean, standard deviation, $\mathbf{n}$ ) and are reported in millimeters unless otherwise noted.

While measuring, an attempt was made to determine the symmetry of each worm. This was achieved by measuring the anterior body portion (ABP) length on each side of the worm. For various reasons, it was not possible to take relevant measurements of all the specimens studied. The following description is based on 23 morphological features from 57 worms collected during the summer of 2000 .

For scanning electron microscopy (SEM), worms were killed, as above, in hot water, then fixed in 3\% glutaraldehyde in $0.1 \mathrm{M}$ phosphate buffer (at $\mathrm{pH} 7.2$ for $2 \mathrm{hr}$ ), washed 5 times in buffer, postfixed in $1 \%$ osmium tetroxide (also in $0.1 \mathrm{M}$ phosphate buffer for $2 \mathrm{hr}$ ), rinsed in distilled water, coated using the ligand-mediated technique of Kelley et al. (1973), and viewed with a Hitachi S-3000N scanning electron microscope. Magnifications are indicated in Figures 2-5. Figure 6 is a composite from several whole mounts and serial paraffin sections (Pritchard and Kruse, 1982) of worms in situ in bladders from 2 hosts.

Specimens were deposited in the Harold W. Manter Laboratory (HWML), University of Nebraska State Museum (UNSM); accession numbers follow the description. Although Ubelaker's description of a new species of Phyllodistomum was never published, he did deposit a "holotype" specimen in the USNM Helminth Collection (No. 60573). This specimen was borrowed, and the same 23 morphological features were measured. However, this specimen is not part of the type series for $P$. funduli.

\section{RESULTS}

Over 850 fish, including 9 different species from 5 different families, were examined, but the only adult helminth discovered in the bladder was the undescribed species of Phyllodistomum Braun, 1899 in F. sciadicus (Table I). In 1999, 79 worms were recovered from 48 infected fish; in 2000, 140 worms were recovered from 81 infected fish; and in 2001, 58 worms were recovered from 38 infected fish. Two of the worms recovered during the summer of 2000 were seen in the ureters. Prevalence ranged from 21 to $42.4 \%$, and intensity of infection ranged from 1.53 to 1.73 .

\section{DESCRIPTION}

Phyllodistomum funduli n. sp. (Figs. 1-6)

Body of mature specimens slightly narrower at anterior end and broader and rounder at posterior end, 1.10-5.49 $(2.06,0.96$, $49)$ long by $0.46-2.73(1.09,0.27,55)$ wide at region of maximum width, level of the anterior testis. Width at intestinal bifurcation, $0.22-1.22(0.47,0.20,51)$ and width at shoulders, $0.22-1.00(0.59,0.23,56)$. Length of right $A B P, 0.46-2.27$ 
TABle I. Prevalence (P), intensity (I), and mean abundance (MA) of Phyllodistomum funduli n. sp. in 9 species* of fish from Cedar Creek, Keith County, Nebraska, during the summers of 1999, 2000, and 2001.

\begin{tabular}{|c|c|c|c|c|c|c|c|c|c|}
\hline \multirow[b]{2}{*}{ Fish species } & \multicolumn{3}{|c|}{1999} & \multicolumn{3}{|c|}{2000} & \multicolumn{3}{|c|}{2001} \\
\hline & $\mathbf{P}$ & I & MA & $\mathbf{P}$ & $\mathbf{I}$ & MA & $\mathbf{P}$ & I & MA \\
\hline Campostoma anomalum & 0 & 0 & 0 & 0 & 0 & 0 & 0 & 0 & 0 \\
\hline n & 16 & & & 1 & & & 14 & & \\
\hline Culaea inconstans & 0 & 0 & 0 & 0 & 0 & 0 & 0 & 0 & 0 \\
\hline $\mathrm{n}$ & 14 & & & 13 & & & 29 & & \\
\hline Fundulus sciadicus & 36.4 & 1.65 & 0.60 & 42.4 & 1.73 & 0.73 & 21.0 & 1.53 & 0.32 \\
\hline n & 132 & & & 191 & & & 181 & & \\
\hline Gambusia affinis & 0 & 0 & 0 & 0 & 0 & 0 & 0 & 0 & 0 \\
\hline n & 23 & & & 52 & & & 85 & & \\
\hline Lepomis cyanellus & 0 & 0 & 0 & 0 & 0 & 0 & 0 & 0 & 0 \\
\hline n & 0 & & & 2 & & & 2 & & \\
\hline Micropterus salmoides & 0 & 0 & 0 & 0 & 0 & 0 & 0 & 0 & 0 \\
\hline n & 0 & & & 7 & & & 29 & & \\
\hline Notropis ludibundus & 0 & 0 & 0 & 0 & 0 & 0 & 0 & 0 & 0 \\
\hline $\mathbf{n}$ & 1 & & & 0 & & & 0 & & \\
\hline Semotilus atromaculatus & 0 & 0 & 0 & 0 & 0 & 0 & 0 & 0 & 0 \\
\hline n & 2 & & & 11 & & & 38 & & \\
\hline Phoxinus sp. & 0 & 0 & 0 & 0 & 0 & 0 & 0 & 0 & 0 \\
\hline n & 3 & & & 5 & & & 0 & & \\
\hline
\end{tabular}

* Phoxinus sp. are hybrids of $P$. eos and $P$. neogaeus.

$(0.82,0.35,49)$ and length of left ABP, $0.41-2.07$ (0.81, 0.34, 49). Body margins very finely papillate; no marginal fold present.

Oral sucker terminal and slightly oval, the mouth opening ventrally; no noticeable papillae on oral sucker. Oral sucker larger than acetabulum. Oral sucker length, 0.20-0.83 (0.33, $0.12,52)$ and width, $0.20-0.78(0.32,0.11,52)$. Acetabulum length, $0.15-0.73(0.29,0.11,57)$ and width, 0.12-0.71 $(0.29$, $0.11,57)$. Sucker ratios: lengths of oral sucker to acetabulum, 1:0.88; widths of same organs, 1:0.93. Esophagus relatively straight, slender; length, $0.02-0.22(0.10,0.04,49)$. No muscular pharynx; intestinal bifurcation preacetabular; ceca not extending past uterus.

Paired vitelline glands posterolateral to acetabulum; oval, rarely lobed, lying close to acetabulum. Right vitelline gland length, 0.07-0.36 (0.18, 0.09, 55); width, 0.05-0.27 (0.09, 0.05, 55). Left vitelline gland length, $0.07-0.49(0.18,0.08,56)$; width, $0.05-0.24(0.08,0.04,56)$. Distance between vitelline glands, $0-0.41(0.14,0.07,57)$. Mehlis' gland posterior to acetabulum, between vitellaria. Ovary amphitypic, sometimes slightly lobed; $0.10-0.51(0.20,0.08,56)$ at greatest width. Uterus extensive, covering most of the hind body, and with many extracecal loops. Egg length, $0.01-0.04(0.03,0.01,285)$ and width, 0.01-0.03 (0.02, 0.04, 285).

Testes located in broadest part of the hind body, placed obliquely, and lobed. Anterior testis usually lateral to ovary. Posterior testis more regularly shaped and slightly larger than anterior testis. Posterior testis length, $0.10-0.85$ (0.24, 0.16, 50); width, $0.07-0.73(0.23,0.13,50)$; anterior testis length, $0.07-0.32(0.21,0.97,52)$; width, $0.05-0.54(0.19,0.10,52)$. Seminal vesicle preacetabular, saclike in appearance.

\section{Taxonomic summary}

Type host: Plains topminnow, F. sciadicus Cope 1865.

Type locality: Cedar Creek in Keith County, Nebraska $\left(41^{\circ} 11.18^{\prime} \mathrm{N}, 101^{\circ} 21.77^{\prime} \mathrm{W}\right)$.
Site of infection: Urinary bladder and ureters.

Specimens deposited: Harold W. Manter Laboratory collection, UNSM, Lincoln, Nebraska (holotype: HWML 16728; 12 paratypes: HWML 16729).

Etymology: The specific epithet is derived from the generic name of the host.

\section{Remarks}

In possessing an oral sucker that is larger than the acetabulum, $P$. funduli n. sp. most closely resembles $P$. unicum Odhner, 1902; P. pearsei Holl, 1929; P. mogurndae Yamaguti, 1934; $P$. brevicecum Steen, 1938; $P$. caudatum Steelman, 1938; $P$. etheostomae Fischthal, 1943; and P. scrippsi Brooks and Mayes, 1975. The new species differs from $P$. etheostomae and $P$. mogurndae in not having a notched posterior end. Also, $P$. funduli has no body fold or other demarcation in the hind body, whereas $P$. etheostomae has been described as having 2 . The new species differs from $P$. caudatum in not having a caudal (taillike) projection. The new species differs from $P$. brevicecum in not having cephalic glands. Phyllodistomum pearsei and $P$. brevicecum differ from the new species in having characteristically small testes, i.e., testes that are smaller than the ovary. Also, $P$. pearse $i$ and $P$. mogurndae differ from the new species in not having an ovary that exhibits amphitypy. Phyllodistomum unicum is almost 3 times larger than the new species. Phyllodistomum funduli differs from $P$. scrippsi in possessing smaller eggs, a shorter esophagus, and a narrower hind body. The structures that appear as small papillae on the oral sucker of Figure 1 (camera lucida drawing) are probably the low ridges that appear in the ventral margin of the oral sucker in Figure 2.

\section{DISCUSSION}

The trematode described in this study seems to be highly host specific. Thus, it was named $P$. funduli n. sp. for the fish defin- 

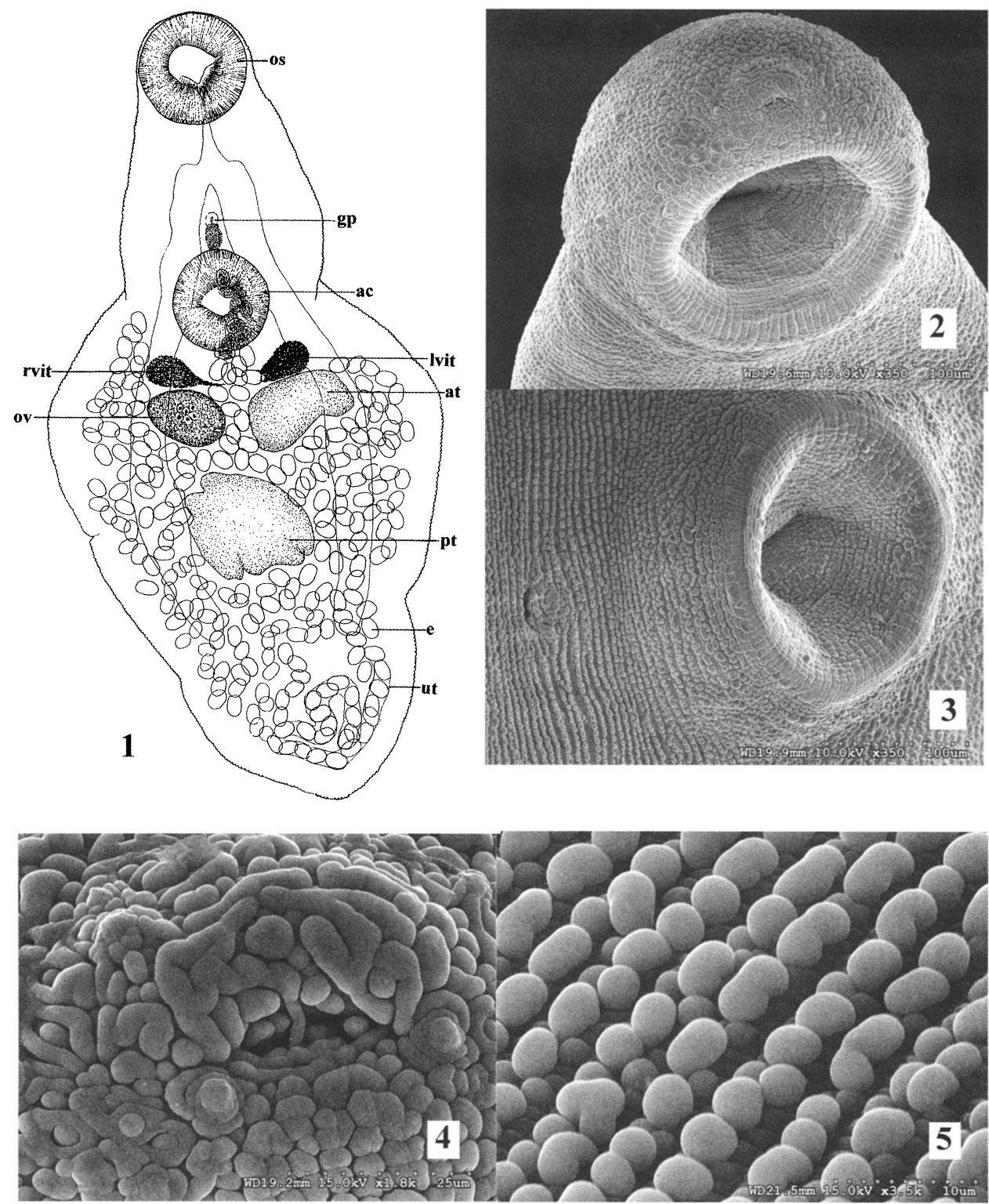

FIGURE 1. Phyllodistomum funduli n. sp. ac, acetabulum; at, anterior testis; e, egg; gp, genital pore; lvit, left vitellarium; os, oral sucker; ov, ovary; rvit, right vitellarium; ut, uterus.

FIGURE 2. Scanning electron microscopy of anterior end of P. funduli, showing oral sucker and small opening interpreted as a stylet scar; magnification $\times 350$.

FIGURE 3. Scanning electron microscopy of acetabulum and genital pore of $P$. funduli; both this figure and Figure 2 show the papillated surface evident along the edges of specimens fixed and stained by standard methods; magnification $\times 350$.

FIGURE 4. Higher-magnification $(\times 1,800)$ scanning electron microscopy of stylet scar.

FIGURE 5. Papillated body surface $(\times 3,500)$.

itive host $F$. sciadicus. However, the actual host specificity of species within Phyllodistomum is not well known (Goodchild, 1943) because most of the information regarding these species is limited to descriptions. Phyllodistomum folium has been reported in at least 10 different species of European Cyprinidae, whereas $P$. megalorchis and $P$. simile can be found in 3 different host species. The remaining phyllodistomes are reported from only 1 or 2 host species (Goodchild, 1943).

A possible explanation for the wide range in host specificity could be found in the life cycle of these species. The known life cycle of Phyllodistomum species can be found in 1 of 3 formats. The most common form in fish is one in which the fluke infects freshwater sphaeriid clams as the first intermediate host and aquatic arthropods as the second intermediate host. The second route is one in which the fluke infects clams as the first intermediate host and fish eat the clams to become infected, and the third form is one in which fish can become infected by either method (Cribb, 1987). However, there are reports that unionid clams also can serve as the first intermediate host in a 2-host life cycle (Orecchia et al., 1975). Therefore, future studies on species within this genus must be conducted to determine whether the host specificity of the phyllodistome is due to the 


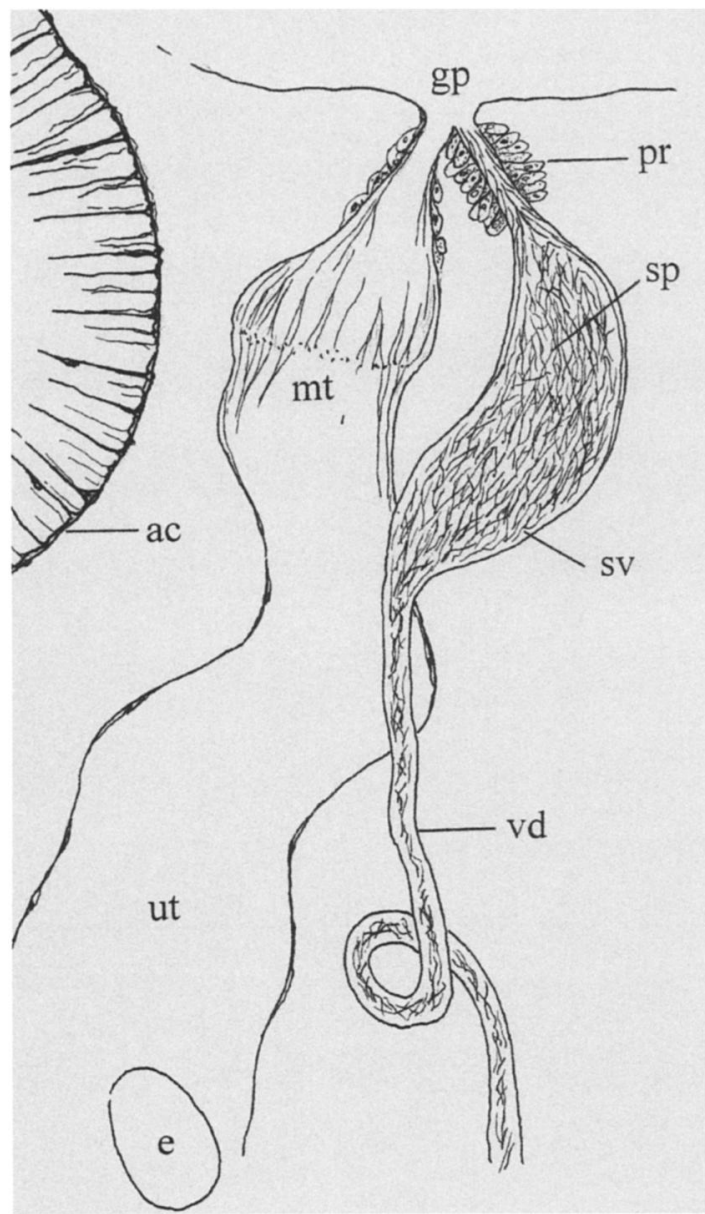

FIGURE 6. Details of the terminal ends of the reproductive tracts. Drawings are based on serial sections of 2 worms in situ. ac, acetabulum; e, egg; gp, genital pore; mt, metroterm; pr, prostate gland; sp, sperm in seminal vesicle; sv, seminal vesicle; ut, uterus; vd, vas deferens.

ecology or the physiology of the host. This in itself presents a problem because only a handful of life cycle studies have been conducted and even fewer have been completely solved by laboratory manipulation.

However, this is not the first time that a species of Phyllodistomum has been collected from the plains topminnow, $F$. sciadicus. In his doctoral thesis, John Ubelaker (1967) examined the life cycles of both $P$. bufonis and a candidate new species found in $F$. sciadicus. His original description of this worm was never published, but he did publish an article on the influence of temperature on the survival and infectivity of miracidia from these 2 species of Phyllodistomum for bivalves (Ubelaker and Olsen, 1970). The number of worms used for measurements was not given in the Ubelaker (1967) thesis. The measurements provided, however, fall within the ranges given in the present study, although they tend to be at the smaller end of this range.

\section{ACKNOWLEDGMENTS}

We thank Gina Todera for providing the 1999 sampling data and Cedar Point Biological Station for use of facilities. We also thank Randy Peterson of Paxton, Nebraska, for allowing us to conduct research on his land and Kit Lee for his assistance with SEM. This work was supported by grants from the Center for Great Plains Studies graduate student Grant-in-aid, University of Nebraska-Lincoln, and the SBS Special Funds Grant, University of Nebraska-Lincoln.

\section{LITERATURE CITED}

Bakke, T. A., AND R. E. BaIley. 1987. Phyllodistomum umblae (Fabricius) (Digenea, Gorgoderidae) from the British Columbia salmonids: A description based on light and scanning electron microscopy. Canadian Journal of Zoology 65: 1703-1712.

BeILfu, E. R. 1954. The life histories of Phyllodistomum lohrenzi Loewen, 1935, and $P$. caudatum Steelman, 1938 (Trematoda: Gorgoderidae). Journal of Parasitology 40: 44.

Brooks, D. R., AND M. A. MAYES. 1975. Phyllodistomum scrippsi sp. n. (Digenea: Gorgoderidae) and Neobenedenia girellae (Hargis, 1955) Yamaguti, 1963 (Monogenea: Capsalidae) from the California sheephead, Pimelometopon pulchrum (Ayres) (Pisces: Labridae). Journal of Parasitology 61: 407-408.

CRIBB, T. H. 1987. A new species of Phyllodistomum (Digenea: Gorgoderidae) from Australian and New Zealand freshwater fishes with notes on the taxonomy of Phyllodistomum Braun, 1899. Journal of Natural History 21: 1525-1538.

Ferdig, M. T., M. A. McDowell, AND J. JANOvy JR. 1991. Salsuginus yutanesis n. sp. (Monogenea: Ancyrocephalidae) from Fundulus sciadicus in Clear Creek of eastern Nebraska. Journal of Parasitology 77: 344-347.

AND R. E. Clopton. 1993. Patterns of morphological variation of Salsuginus yutanensis (Monogenea: Ancyrocephalidae) over space and time. Journal of Parasitology 79: 744-750.

Fischthal, J. H. 1943. A description of Phylodistomum etheostomae Fischthal, 1942 (Trematoda: Gorgoderidae), from percid fishes. Journal of Parasitology 29: 7-9.

Goodchild, C. G. 1943. The life history of Phyllodistomum solidum Rankin, with observations on the morphology, development and taxonomy of Gorgoderinae (Trematoda). Biological Bulletin 84: 59-86.

Hoffman, G. L. 1999. Parasites of North American freshwater fishes, 2nd ed. Cornell University Press, Ithaca, New York, 539 p.

Holl, F. J. 1929. The phyllodistomes of North America. Transactions of the American Microscopical Society 48: 48-53.

Kelley, R. O., R. A. F. DeKker, AND J. G. Bluemink. 1973. Ligandmediated osmium binding: Its application in coating biological specimens for scanning electron microscopy. Journal of Ultrastructural Research 45: 254-258.

Lee, D. S., C. R. Gilbert, C. H. Hocutt, R. E. Jenkins, D. E. MCAllister, AND J. R. Stauffer JR. 1980. Atlas of North American freshwater fishes. North Carolina State Museum of Natural History, Raleigh, North Carolina, 854 p.

ODHNER, T. 1902. Mitteilungen zur Kenntnis der Distomen, I. Zentralblatt für Bakteriologie und Parasitenkunde-Originale 31: 58-69.

Orecchia, P., L. Paggi, L. Castagnolo, G. Della Seta, and R. MiNERVINI. 1975. Ricerche sperimentali sul ciclo biologico di Phyllodistomum elongatum Nybelin, 1926 (Digenea: Gorgoderidae Looss, 1901). Parassitologia 17: 95-101.

Pritchard, M. H., AND G. O. W. KRUSE. 1982. The collection and preservation of animal parasites. University of Nebraska Press, Lincoln, Nebraska, $141 \mathrm{p}$.

RaI, S. L. 1964. Observations on the life-history of Phyllodistomum srivastavai sp. nov. (Trematoda: Gorgoderidae). Parasitology 54: 43-51.

Schell, S. C. 1967. The life of Phyllodistomum staffordi Pearse, 1924 (Trematoda: Gorgoderidae Looss, 1901). Journal of Parasitology 53: 569-576.

Steelman, G. M. 1938. A description of Phyllodistomum caudatum n. sp. American Midland Naturalist 19: 613-616.

SteEN, E. B. 1938. Two new species of Phyllodistomum (Trematoda: Gorgoderidae) from Indiana Fishes. American Midland Naturalist 20: $201-210$.

Thomas, J. D. 1956. Life-history of Phyllodistomum simile Nybelin. Nature 178: 1004.

Ubelaker, J. E. 1967. Studies on the trematode genus Phyllodistomum. 
Ph.D. Dissertation. Colorado State University, Fort Collins, Colorado, $137 \mathrm{p}$.

Ubelaker, J. E., AND O. W. OlsEN. 1970. Influence of temperature on survival rate and infectivity of miracidia of two species of Phyllodistomum (Trematoda) to pelecypods. Journal of Invertebrate Pathology 16: 363-366.
, AND - 1972. Life cycle of Phyllodistomum bufonis (Digenea: Gorgoderidae) from the boreal toad, Bufo boreas. Proceedings of the Helminthological Society of Washington 39: 94-100.

YamaGuTI, S. 1934. Studies on the helminth fauna of Japan. Part. 2. Trematodes of fishes, I. Japanese Journal of Zoology 5: 249541. 